\title{
福島原子力発電所事故の原因分析に基づく 工学教育改善策の提案
}

Proposal for Improvement of Engineering Education from the Analysis of the Cause of Accident at Fukushima Nuclear Power Plant

\author{
田 岡 直 規*1 \\ Naoki TAOKA
}

\begin{abstract}
Nowadays, even if individual engineers are aware of technical risk within the scope of direct responsibility, it is difficult to exhaustively and accurately grasp and recognize the technical risk of the huge, synthesized and complicated science and technology as a whole. Under "uncertainty of science and technology", cases are increasing in which engineers are forced to make decision. Under such circumstances, recently, similar artificial accidents and scandals are frequently occurring, and improvement about ability required of engineers and engineering education, is demanded. Therefore, "Fukushima Nuclear Power Plant" is taken up as a representative example of science and technology of hugeness, synthesis and complication, under uncertainty, from the analysis of the cause of the accident, ability required of future engineers is organized and improvement on engineers ability required by JABEE and engineering education is proposed.

Keywords : Fukushima Nuclear Power Plant Accident, Engineering Education, Uncertainty, JABEE, Ability of Engineer

キーワード：福島原子力発電所事故，工学教育，不確実性，JABEE，技術者能力
\end{abstract}

\section{1.はじめに}

現代では原子力発電所等に代表されるように，科学技 術の巨大化・総合化・複雑化により，個々の専門技術者 が，直接責任をもつ範囲において技術的リスクを認識し ていたとしても，巨大化・総合化・複雑化した科学技術 全体がもつ技術的リスクについて, 網羅的に的確に把握・ 認識することは困難である ${ }^{1)}$ 。また，科学技術は，常に 「未知」の部分を含みながら, その未知の部分の解明, 知 識形成が「現在進行形」で時々刻々と進められている2). すなわち「科学技術の不確実性下」で, 科学者, 技術者 等が意思決定を迫られるケースが増加しつつある.

しかし，日本の技術者は，所属する組織の方針，施策， 文化に大きく影響されると同時に，必ずしも自律したプ ロフェッショナルとして認められていない.

そのような中, 昨今, 原子力トラブル, データ不正, 品質偽装等の, 技術者が関与する類似の人為的な事故 · 不祥事が頻発しており,「技術者に求められている能力」 や工学教育等について, 改善が求められている。 そこで, 「巨大化・総合化・複雑化，および不確実性下」の科学技 術の代表事例として,「福島原子力発電所」を取り上げ, その事故原因の分析から,「これからの技術者に求められ る能力」を整理し,「JABEEで求められている技術者能 力」, 工学教育について改善すべき点を提案する。

2018 年 3 月 8 日受付

※1公益社団法人日本技術士会近畿本部

\section{2. 事例分析：福島原子力発電所事故}

「科学技術の巨大化・総合化・複雑化，抒上び不確実 性下の工学教育はどうあるべきか？」「巨大化・総合化・ 複雑化, 抄よび不確実性下」の科学技術の代表事例とし て,「福島原子力発電所」を取り上げ, まず 4 つの事故調 查委員会資料 ${ }^{3)-7)}$ 等を分析し, 事故原因として何が指 摘されているかをまとめた，全交流電源と直流電源を言 失し原子炉を安定的に冷却する機能が失われたことが, 今回の大事故 (炬心溶融, 水素爆発, 放射性物質の大量 拡散）の直接的原因である ${ }^{4)-6)}$ が，それ以外の要因も 指摘されている. 本論文では, それらの資料を基に, 事 故前の，1.リスク認識，2. 技術思想の伝承，3. 法律， 技術基準, 安全基準, という観点から, また事故時, 事 故後の, 4. 安全管理, 5.リテラシー, の観点から, 事 故の遠因と背景（「事故原因」と総称する）の分析を行っ た，以下各項目について，詳細に述べる（表 1$)$.

\section{1 リスクの認識}

もともと, 福島原子力発電所事故時に, 国, 原子力事 業者をはじめとした「原子力村」全体を覆っていた「安 全神話」や「米国導入技術への盲信」は，この福島原発 事故へどのような影響を与えたのであろうか?

また, 事故の直接的原因となった日本固有の巨大地震, 巨大津波というリスクに対し，国や原子力事業者はどの ように認識し，対応していたのだろうか？

\section{(1) 安全神話依存}

原子力エネルギーの平和利用として高らかに宣伝され 
表 1 福島原子力発電所事故：事故原因と対策

\begin{tabular}{|c|c|c|c|}
\hline & 項 & 事 故 & 対 \\
\hline 1 & リスクの認識 & $\begin{array}{l}\text { (1)安全神話依存 } \\
\text { (2)リスク認識誤り } \\
\text { (3)中枢部多重防護システム依存 } \\
\text { (4)米国導入技術への盲信 }\end{array}$ & $\begin{array}{l}\text { (1)安全神話からの脱出 } \\
\text { (2)リスク認識力、リスク対応力の向上 } \\
\text { (3) システム依存からの脱出. } \\
\text { 周辺部も含めた安全管理への移行 } \\
\text { (4)米国導入技術への盲信からの脱出 }\end{array}$ \\
\hline 2 & 技術思想の伝承 & $\begin{array}{l}\text { (1)技術思想の未伝承：米国仕様品（地震フ } \\
\text { リー, 内陸部設置）の導入 }\end{array}$ & $\begin{array}{l}\text { (1)技術思想の伝承：日本仕様品（巨大地震, } \\
\text { 海岸設置）としての設置 }\end{array}$ \\
\hline 3 & 法律、技術基準、安全基準 & (1)40年前の法律, 技術基準, 安全基準の踏襲 & (1)最新の技術的知見の反映 \\
\hline 4 & 非常用装置の使用 & (1)事故時の非常用装置作動誤認 & (1)非常用装置の作動理解と日常訓練 \\
\hline 5 & リテラシー & $\begin{array}{l}\text { (1)公衆の科学技術リテラシー, 技術者の社会 } \\
\text { リテラシーの欠如 }\end{array}$ & $\begin{array}{l}\text { (1)公衆の科学技術リテラシーと技術者の社会 } \\
\text { リテラシーの向上及び融合 }\end{array}$ \\
\hline
\end{tabular}

る中, 早急な商業炉の導入を求める電力会社の要請に基 づき，原子力の政策決定者，専門家や関係者はその経済 的優位性を盲信，主張し，短期間に原子力発電所の大型 化，商業化を推進した。一方，原子力に潜在する事故， 放射線被曝，環境污染や放射性廃棄物等の危険性やリス ク，さらに技術的あるいは，倫理的な問題に何ら言及し なかった。また，社会に対して何ら警告を発しなかっ $た^{8)}$.

さらに, 国も原子力事業者も, 何ら社会に対しても情報 を公開せず，わが国の原子力発電所では炉心溶融のよう な樑刻なシビアアクシデントは起こりえないという「安 全神話」を主張し続けた。

過去からスリーマイル島原発事故，チェルノブイリ原 発事故, JCO 臨界事故と原子力発電所全体の危険性, 技 術的リスク，を認識しながら,「絶対安全」という安全神 話の集団思考に陥っていた。ささらに,「原子力村」の中で の意思決定に閉じ込め, 社会に対して何ら警告を発する ことなく, ここまで進めてきてしまった.

日本原子力学会標準委員長の宮野廣氏は, 「一面から見 た安全尺度の採用と過信」を事故の遠因に挙げ,「わが国 の原子力発電所では, 計画外スクラム (停止) の頻度が 極めて低いことは世界的にも有名である。，そこに安全神 話が形成されてしまったのではないか，従って，確率論 的安全評価（PSA）のニーズが少なく,「せっかく安全だ というのに」という思いから, 取組が遅れてしまったの ではないか」と述べている ${ }^{5)}$ 。このことは，樑層防護の 考え方の根本である防護レベルの独立性が，十分に理解 されていなかったことを示している。つまり，第1層の 指標である計画外停止頻度だけでなく，第 3 層の指標で ある炉心損傷確率についても，より積極的に評価される べきであった．また評価結果に基づいて，プラントの弱 点を明らかにし，対策を追加する必要があった ${ }^{5)}$.

技術者自身が設計, 試作したもの, 或は日常的に操作し ている装置については, 非常時でも適切な操作が可能で ある. しかし, 福島原発事故での外部電源や非常用ディ ーゼル発電機, スリーマイル島原発事故での ECCS (緊急 炬心冷却装置）のような非常用装置について，特に「絶 対安全」という安全神話にとらわれていた事業者にとっ ては, 技術者自身に設計・試作・操作・訓練経験がなく, 非常時には適切な操作は不可能であった，特に, 福島原
発事故については, フルターンキーで米国から導入した という事情を考虑すればな执さらである ${ }^{8)}$.

このように,「絶対安全」という「安全神話」が原子力 発電所の適切な安全管理を疎かにさせるとともに, 思想 面で大きな事故原因となったことは否めない.

「絶対安全」という,「安全神話」からの適切な脱出が 必要である.

(2) リスク認識䛊り

元来, 地震や津波等に代表される自然は不確実性を備 えており, 自然現象の予測は容易ではなく ${ }^{9)}$, いも「想 定外」の事象が発生しており, 従来の科学技術だけでは, 十分に制御することができない.

実際に, 阪神・淡路大震災, 新潟県中越沖地震をはじ め原子力事業者の想定を超える天災は, これまで何度と なく発生している。 また，日本では869年には貞観津波 が, 発生している。

福島第一原子力発電所が原子炉の設置許可を取得した のは1966〜 72年であるが, 1970年以前は津波についての 明確な基準がなく, 電力事業者は既知の津波痕跡をもと に設計を行い, 結果として, 小名浜港工事基準面 $+3.122 \mathrm{~m}$ (当時小名浜港で観測されていた既往最大の1960年チリ 地震津波の潮位）を設計条件として定めた ${ }^{51}$.

電力事業者は2002年 2 月，土木学会が新たに津波評価

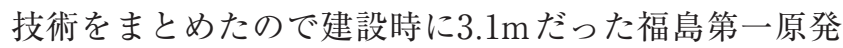

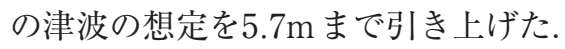

また，日本政府が2006年に原子力発電所の新耐震指針 を制定したのを受けて耐震性評価のための専門家委員会 が2009年 6 月に開かれた。その席で地質学の専門家であ る独立行政法人産業技術総合研究所 活断層・地震研究七 ンターの岡村行信センター長が, 869年に三陸沖を震源と する貞観地震が発生した際, 大津波が仙台以南にも押し 寄せたと指摘した ${ }^{10)}$.

岡村氏はさらに同規模の津波が450～800年程度の再 来間隔で過去に繰り返し起きていたこともわかり，近い 将来に再び起きる可能性も否定できない ${ }^{11)}$ と警告を発し ていた.

一方，電力事業者は三陸沖の波源モデルをもとに津波 を試算し, 最大で $15.7 \mathrm{~m}$ の津波が起こり得るとの試算を 出した。防波堤を設置すれば，数百億円の費用と 4 年か かる見込みとなる。最終的に「実際には津波はこない」 
と考え, 電力事業者社内ではこれ以上の対応をせず, 政 府事故調查報告書では，津波問題について「重要な問題 として認識されていた形跡はうかがわれない」としてい $ろ^{5)}$.

また，福島第一原子力発電所でも，長期にわたる全交 流電源喪失の危険性は認識されており，一部それに対す る対策もとられていた， 1 号機では，各 2 台の非常用デ イーゼル発電機が配備されていた。 さらに, シビアアク シデント対策として, 電源融通用のケーブルが敷設され ていた。 これらの対策にもかかわらず， 1 号機が全電源 喪失に陥ったのは，生き残った発電機を接続していた金 属閉鎖配電盤等が浸水したためである ${ }^{5)}$.

このように，巨大地震，巨大津波というわが国に固有 のリスクに対して, リスク想定, リスク対応がきわめて 不十分で, その結果重大な事故を起こしたといえる.

巨大地震，巨大津波等，特に巨大リスクへのリスク認 識力, リスク対応力の向上が必要である.

（3）中枢部多重防護システムへの依存

原子力発電所の中枢部分は, 放射性物質が漏れないよ うにつくられた，多層にもわたる物理的な障壁から構成 されている，具体的には燃料ペレット (第 1 の壁), 燃料 被覆管（第 2 の壁）, 原子炉圧力容器 (第 3 の壁), 原子 炉格納容器（第 4 の壁）, 原子炉建屋（第 5 の壁）の 5 重 の壁から構成されている.

元来, 技術者は, 各専門分野の技術の安全性評価・管 理はできるが，巨大化・総合化・複雑化した科学技術で ある原子力発電所全体のシステムの構成や，トラブル . 事故に備えての多重制御, さらには非常用電源装置, 防 波堤等の周辺部を含めたシステム全体の安全性の評価・ 構築・管理ができていないのが現状である ${ }^{12)}$.

また, わが国では, 定期検查などの枠組みの中で, 個 別の機器や構造物の性能が, 定期的, かつ詳細に評価さ れてきた経緯がある。従って, 海外と比較して, 個別の 機器の信頼性は高い傾向にある。一方で, プラント全体 の安全性については, 評価が不十分であった可能性が指 摘できる ${ }^{5}$.

すなわち, 確かに原子力発電所という巨大化・総合 化・複雑化した科学技術であるシステムに㧈いて中枢部 分は高い安全設計であった。しかし, 今回の大震災にお ける外部電源や非常用ディーゼル発電機の電源墠失のよ うに，周辺部に抒いて，見落としがあるとエラーが発生 しやすく，巨大化・総合化・複雑化したシステム全体が 機能不全に陥る場合がある. システムの中枢部分だけで はなく, 周辺部も含めたシステム全体の安全性評価・構 築・管理等のハード面での対策と同時に「想定外」を想 定した防災訓練，あるいは致命的な被害には至らない減 災訓練等のソフト面での対策が必要である ${ }^{12)}$.

例えば，全電源喪失を想定したバッテリーを含めた電 源配置の多様性, 注水 ·冷却設備の多重性, 可搬式の安 全設備の準備等による柔軟な対応策の整備，さらに迅速 なバルブの手動開閉操作による減圧作業等の訓練等, 想 定可能な準備・訓練を重ねておれね゙このような大惨事に 至らなかったはずである ${ }^{5)}$.
中枢部だけでなく, 周辺部も含めたシステム全体の安 全管理への移行が必要である.

(4) 米国導入技術への盲信

原子力発電所については, 米国からフルターンキーで 導入し, その導入当初からハード面, ソフト面でも 40 年 以上前の米国の技術や思想を基本にした法律, 安全基準, 技術基準，知見等，それを基に国によって策定されたマ ニュアル, 基準, 規格を盲信し, 遵守することのみを最 優先した。 そのため, その本来の技術の背景や考え方を 学び,「危険性」や「リスク」を評価し, 社会に対し必要 な「警告」をするという本来必要なアプローチを実施し ていない8).

当時の社会的背景として, 科学技術全般に対する社会 的な信頼が高く, 原子力技術自体が外国からの輸入技術 であったため, 外国で設定された安全基準を維持すれば 原子力安全は保障されるとの強い共通認識があった ${ }^{5)}$.

しかし, 法律や安全基準等は過去の経験や経済性等を 考慮したある水準を守ることを義務付けられたものであ る.

法律や安全基準等を遵守するだけでは,「想定内」での 安全確保ができたとしても「想定外」の事象を含めて, 特に「作動中の科学」に対しては, 絶対安全というわけ ではない，すなわち，不確実性があり，予測が容易でな い自然現象や自然のリスクに対して, 国の認可や法律, 安全基準だけでは，事前に「想定外」の自然のリスクや それに伴う連鎖反応的な「負の効果」を防ぐことはでき ないのである。まして電力事業者が「原子力発電所が国 の指針に適合している」ことさえ立証すれば事業者の社 会的責任を果たしたことにならないのは言うまでもな $w^{12)}$.

このように, 米国からの導入技術への盲信が,「安全管 理」を踈かにさせるとともに，思想面で大きな事故原因 となったことは否めない.

「米国導入技術への盲信」からの適切な脱出が必要で ある。

\section{2 技術思想の伝承}

今回, 事故が発生した福島第一原子力発電所は, 40年 以上前に米国から導入された技術であるが，そもそも米 国から日本に技術思想が正しく伝承され設置されたので あろうか?

わが国では，原子力政策により，この地震大国で津波 の被害を避けることができない海岸に54基もの原子力発 電所を建設・稼動させてきた。

そもそも 40 年以上前に米国から導入した原子力発電所 は, 米国固有の, (1)大地震が想定されない, (2)内陸部の 大河近くに設置する，という設置環境を想定したもので あり, 地震大国で海岸に設置せざるを得ないという日本 固有の設置環境を考慮したものではなかった ${ }^{8)}$.

実際に，米国では，原子力発電所は主に東部の内陸部 の大河近くという巨大地震の発生実績がない, また津波 の影響もない環境に設置されているが, 日本は地震大国 であり, 海岸という, 巨大地震・巨大津波という日本固 有のリスクが存在する環境に設置せざるをえない. 
この米国からの導入技術に対し，海の近くに設置する という日本固有での設置環境を考慮せず，又地震大国で あり貞観地震レベルの巨大地震・巨大津波という日本固 有のリスクが存在するにもかかわらず，安全性評価，リ スク評価を十分に行わなかった.

そもそも米国から導入した原子力発電所の「技術思想」 が米国から日本へ正しく伝承され，運用されたとは考え られない。

米国仕様品の導入にあたり, 適切に日本仕様品として 設置するという，技術思想の伝承が必要である。

\section{3 法律，技術基準，安全基準}

それでは，米国からの導入技術である福島第一原子力 発電所の「法律, 技術基準, 安全基準」については, ど のように伝承され，運用されたのであろうか？

新しい原子力発電所はその時代時代の法律, 技術基準, 安全基準，知見に基づいた設計・建設・設置等が行われ ている.

40年も前に米国から導入され，設置された巨大化・総 合化・複雑化した科学技術である福島第一原子力発電所 は，ハード面，ソフト面でも40年前の法律，技術基準， 安全基準, 知見に基づくと同時に, 米国での設置環境を 想定した科学技術である ${ }^{12)}$.

一方, 福島第一原子力発電所が稼動してからの約 40 年 の間に，科学技術は急速に発展し，この貞観地震をはじ め稼動当初は想定できなかった地震や津波, さらにそれ に伴う被害の発生も予見できるようになってきている. また, 全電源喪失は米国で30年前に想定されている ${ }^{13)}$. さらに，2010年10月に公表された経済産業省所管の原子 力安全基盤機構による電源喪失における圧力容器破損の シミュレーション結果のように, 原子力発電所の電源喪 失が起きることを想定していた研究も存在する ${ }^{14)}$.

一方原子力安全機構が2010年に公表したこのシミュレ ーションによると, 電源を喪失し, 冷却機能を失った原 子炬は，わずか 1 時間40分ほどで核然料が溶け出すとい う炬心溶融を起こすなど, 短時間で危機的状況に陥るこ とが指摘されていた ${ }^{15)}$.

それにもかかわらず, 電力事業者は外部電源や非常用 ディーゼル発電機の電源機能を長時間失う事態をいずれ も想定されていたが，対策に取り組むと膨大なコストを 必要とするため, 経済性等を考慮して想定から外された という「想定外」とし, この科学技術成果, 研究成果, 知見を, 技術基準, 安全基準に反映しなかったのである. 国も経済性の理由から，また絶対安全という建前上から 「送電線の復旧, 非常用発電機の修復が期待できるため考 慮不要」15) と了承していたのである.

さらに, 原子力関連の科学者, 技術者は, 原子炉の冷 却停止シミュレーションや放出された放射性物質の拡散 シミュレーションと, 多くの有効な科学的知見を見出し ていながら, 直接, 安全基準, 行動基準等に十分に生か されなかった。

また，その後も40年前の法律，技術基準，安全基準を 踏襲し, 現在進行形で急速に発展する科学技術研究の未 知の部分の解明を行うという原子力関連の科学技術成果
や地震, 津波等自然災害に関するいわゆる「作動中の科 学」の研究成果や知見をこの巨大化・総合化・複雑化し た科学技術に十分に反映しなかったのである ${ }^{12)}$.

\section{4 非常用装置の使用}

それでは, このような, リスク認識, 技術思想, 法律, 技術基準, 安全基準に基づいた事故時の非常用装置はど のように使用されたのであろうか?

事故時には, 通常, IC (非常用復水器) が作動し, 非 常時の冷却機能を活用できる仕組みになっている。しか し, 1 号機の運転員は, ICに対する理解不足と不十分な 訓練により， 1 号機のIC作動状況を誤認しICによる冷 却機能を活用できなかったことは重大なヒューマンエラ 一である.すなわち, ICが作動していると思い込み, 冷 却機能が途絶えたことに気づかず，(1)消火ポンプや消防 車を使った 1 号機原子炬への代替注水を直ちに行わなか ったことや，(2)格納容器のベントを11日夜までに速やか に行わなかったことが事態を決定的に悪化させたとして いる5).

技術者自身が設計, 試作したもの, 或は日常的に操作し ている装置については, 非常時でも適切な操作が可能で ある。しかし, スリーマイル島原発事故での ECCS (緊急 炉心冷却装置）のような非常用装置について，特に「絶 対安全」という安全神話にとらわれていた事業者にとっ ては, 技術者自身に設計・試作, 操作・訓練経験がなく, 非常時には適切な操作が不可能であった. 非常用装置に ついて, 日常からの理解, 操作訓練が必要である.

2.5 公衆の科学技術リテラシーと技術者の社会リテ ラシー

公衆には，いわゆる科学技術が十分に理解できないた め, 科学技術に携わる者, すなわち技術者, 研究者が, 公衆に理解できるように, 読み書きする能力, すなわち, 科学技術リテラシーを伝授させることが必要不可欠であ る. 一方, 技術者, 研究者は自己の専門分野の科学技術 そのものには詳しいが, 社会環境が急激に変化する中, その科学技術を, 社会に適用する場合, どのように展開 していくかを読み書きする能力, 社会リテラシーを的確 に身につけることが必要である。

原子力の政策決定者，専門家や関係者は，原子力に潜 在する事故, 放射線被曝, 環境污染や放射性廃裹物等の 危険性やリスク, さらに技術的あるいは, 倫理的な問題 について, 社会に対して何ら警告を発することなく, こ こまで進めてきてしまったことは, 社会リテラシーの欠 如にも起因すると言わざるをえない.

今回の福島原子力発電所事故において「原子力におけ る技術者」はこの原子力という科学技術の「危険性」,「リ スク」の実態を正確かつ迅速に社会に説明し, 警告を発 し「リスク受容」について公衆との間に, 社会的合意を 形成しなかったことは, 社会リテラシーの欠如に起因す るところが少なくない.

特に低線量放射線の人体への影響, 住民への避難勧告, 農作物の出荷制限等において, 科学的知見のもとに意思 決定が求められたが, その過程で混乱を招く結果となっ た.さらには原子力発電所事故後にSPEEDIの解析結果 
が速やかに公開されずに，一部の住民が本来回避可能な 放射線被爆を受けるという事例も発生した。ささらに，事 故の進展や避難に資する情報が住民に伝えられず，多数 回の避難移動, 線量の高い地域への避難等, 被害拡大に 繋がった.

今回の大震災, 原子力発電所事故を踏まえて, 特に現 在進行形の被害拡大防止等という緊急時の科学コミュニ ケーションの仕組みの構築が求められている.

今回の大震災や原子力発電所の事故の事例からもわか るように,「想定外」の事象や，デー夕，あるいは解釈 が困難なデータが存在する場合は,「正確」「詳細」かつ 「迅速」な社会や公衆への説明が困難になり, さらに, 社 会的な合意形成は困難になる。

また，このような状況下では，技術者と公衆の双方向 のコミュニケーション, 及び相互理解が不可欠であり, 本来, 科学者, 技術者は, 公衆に情報を適宜, 適切な方 法で提供することにより，情報公開し，公衆への説明責 任を果たすことにより，公衆の科学技術リテラシーと技 術者の社会リテラシー, 及び双方のリテラシーの向上, 融合を図る必要がある。

\section{3. 事例分析から導かれる技術者に求められる能力}

以上の事例分析に基づき，「技術者に求められる能力」 について, (a) 知識, (b) 態度, (c) スキル, の観点から 分析を行った.

\section{1 リスク評価}

(1) 安全神話から脱出

(a) 知識：「安全神話」の実態と関連事項についての 知識と理解

そもそも「安全神話」の実態とはどのようなもので あろうか? 「安全神話」の実態と関連事項について, 以下 1 ）から 4) についての知識と理解が必要である.

1 ）「安全神話」とは, 原子力発電所の中枢部分は, 放 射性物質が外に漏れないように作られた, 多層にも わたる物理的な障壁，具体的には燃料ペレット（第 1 の壁), 燃料被覆管 (第 2 の壁), 原子炬圧力容器 (第 3 の壁), 原子炉格納容器 (第 4 の壁), 原子炉 建屋（第 5 の壁）の 5 重の壁から構成されていると いう多重防護（深層防護）によるものであり，また 誤操作, 異常時は原子炉の運転が自動的に安全に停 止するよう設計されていると理解されているとい うこと.

2 ）原子力に潜在する事故, 放射線被曝, 環境污染や 放射性廃衰物の危険性やリスク，技術的，倫理的問 題.

3 ）深層防護の考え方の根本である防護レベルは独立 性があり，第 3 層の指標である炉心損傷確率につい ても積極的に評価すべきであるということ ${ }^{5)}$.

4 ）同様の「安全神話」を有しながらも過去に発生し たスリーマイル島原発事故, チェルノブイリの原発 事故の内容と原因.

（b）態度：本当に安全ということを実際に確認する姿 勢
三現主義に基づいて，実際に自分で現物・現場・現 実を確認し, 原子力発電所は安全かを確認する姿勢が 必要である.

（c）スキル：事故・故障を想定する力

「想定外」の巨大地震 - 巨大津波と, それに伴う原 子力発電所に関わる事故・故障を事前に想定する力が 必要である。

（2）適切なリスク想定と対応力

(a) 知識：自然然現象の影響, リスクを理解する力

過去の巨大地震や巨大津波等の自然現象とそれらの 原子力発電所への影響, 公衆に対するリスクについて の知識と理解が必要である。

（b）態度：自然現象の影響・リスクを正しく評価・伝 達する姿勢

過去の巨大地震や巨大津波等の自然現象・リスクの 実態を自ら想定, 確認し, 現行の原子力発電所への影 響, 公衆等へのリスクを評価し，関係者に正しく伝え ようとする姿勢が必要である.

（c）スキル：自然現象のリスク想定力と対応力

原子力発電所等への影響, 公衆等へのリスクを想定 し, 防災訓練・減災措置等の具体的な対応力が必要で ある。

（3）システム依存からの脱出

(a) 知識：中枢部多重防護システムの理解

「原子力発電所の中枢部多重防護システムを中心と した安全管理システム」,「スリーマイル島原発事故等 過去の類似の冷却材喪失事故や周辺部に起因した事 故」, についての知識と理解が必要である.

(b) 態度 : システム全体の安全性評価・構築・管理す るという姿勢

安全システムに依存するだけでなく，自らがシステ ムの中枢部分だけでなく周辺部も含めたシステム全 体の安全性評価・構築・管理するという姿勢が必要で ある。

ハード面での対策と同時に「想定外」を想定した防 災訓練，あるは致命的な被害には至らない減災訓練等 のソフト面での対策も行うという姿勢が必要である.

（c）スキル：事故対応策の想定・準備と訓練

全電源喪失を想定したバッテリーを含めた電源配置 の多様性, 注水・冷却設備の多重性, 可搬式安全設備 の準備等による柔軟な対応策の整備と訓練, さらには 迅速なバルブの手動開閉操作による減圧作業等の訓 練等, 安全管理面で想定可能な準備と訓練能力が必要 である。

(4) 米国導入技術への盲信から脱出する力

（a）知識：マニュアル・基準・規格の根拠 ・ 背景・設 定過程，考え方の知識と理解

マニュアル・基準・規格の根拠やその背景, 設定され た過程, 考え方についての知識と理解が必要である.

（b）態度：マニュアル・基準・規格の根拠を確かめ, 危険・リスクを評価する姿勢

三現主義に基づいて，実際に自分でマニュアル・基 準・規格の根拠を確かめると同時に，危険・リスクを 
評価する姿勢が必要である.

（c）スキル：米国導入技術を国内基準で評価する力

米国からの導入技術を，国内での安全基準，技術基 準, 知見等に基づいて評価する力が必要である.

\section{2 技術思想の伝承}

(a) 知識：正確な技術思想の知識と理解

40年以上前に米国から初めてフルターンキーで導入し た原子力発電所については, 「地震の発生しない内陸部の 大河近くに設置するという米国仕様に基づいたものであ り, 巨大地震が発生する海岸に設置せざるを得ないとい う日本仕様との差異の知識と理解が必要である.

（b）態度：技術思想を適切に変更設定する姿勢

常に各導入技術についての技術思想を理解し, 状況に 応じ適切に変更設定しようとする姿勢が必要である。

(c) スキル：科学技術コミュニケーション能力

正確な技術思想を理解し, 適切に変更設定し, 関係者に 伝える科学技術コミュニケーション能力が必要である.

\section{3 法律，技術基準，安全基準}

(a) 知識：最新の技術的知見を理解する能力

現行の原子力発電所に関する法律, 技術基準, 安全基 準と，それらに関する最新の技術的知見についての知識 とを理解する能力が必要である。

（b）態度：最新の技術的知見を取り入れ反映しょうとす る姿勢

現行の原子力発電所に関する法律, 技術基準, 安全基 準にとらわれず，必要に応じて見直し，最新の技術的知 見を取り入れ反映しようとする姿勢が必要である.

(c) スキル：最新の技術的知見を取り入れ反映する能力

現行の法律, 技術基準, 安全基準にとらわれず, 必要 に応じて見直し，最新の技術的知見を取り入れ反映する 能力が必要である。

\section{4 非常用装置の作動}

(a) 知識：非常用装置の作動原理 - 作動状況の理解

IC (非常用復水器) 等非常用装置についての作動原 理と非常時の作動状況についての知識と理解が必要であ る.

（b）態度 : 非常用装置の日常からの操作訓練姿勢

IC 等非常用装置について, 非常時に備え日常から操作 訓練しようとする姿勢が必要である.

（c）スキル：非常用装置の非常時の操作能力

IC 等非常用装置について, 事故等の非常時に適切に操 作できる能力が必要である。

\section{5 リテラシー}

(a) 知識：公衆の科学技術リテラシーの内容と公衆の懸 念・ニーズについての知識・理解

原子力に潜在する事故, 放射線被曝, 環境污染や放射 性廃裹物等の危険性やリスク，さらに技術的あるいは倫 理的な問題について, 公衆の科学技術リテラシーを向上 させると同時に, その公衆の科学技術リテラシーの内容 さらに, 公衆の要望, ニーズ, 懸念について理解するこ とが必要である。

（b）態度：原子力に関する危険性, リスク, 問題につい て社会に公開し警告を発する態度
原子力の専門家や関係者は，その経済的優位性を盲信 せずに, 原子力に潜在する事故, 放射線被曝, 環境污染 や放射性廃衰物等の危険性やリスク, さらに, 技術的, 倫理的問題点について, 社会に公開し, 公衆の科学技術 リテラシーを向上させると同時に, 社会に警告を発する 態度が必要である。

(c) スキル：公衆の科学技術リテラシーと技術者の社会 リテラシーの向上と融合

技術者と公衆の双方向のコミュニケーション, 及び相 互理解が不可欠であり，本来，技術者は，公衆に情報を 適宜，適切な方法で提供することにより，情報公開し， 公衆への説明責任を果たすことにより，公衆の科学技術 リテラシーの向上, 技術者の社会リテラシーの向上, 及 び双方のリテラシーの融合を図ることが必要である.

\section{4.これからの工学教育に求められる技術者の能力}

4. 1 「JABEEが定める学習・教育到達目標」 ${ }^{16)}$

1999年に設立された日本技術者教育認定機構（以下 $\lceil\mathrm{JABEE}\rfloor)$ では,「JABEEが定める学習・教育到達目 標」において,「技術者に求められている能力」として, 以下の通り定められている.

(a) 地球的視点から多面的に物事を考える能力とその素 養

（b）技術が社会や自然に及ぼす影響や効果，及び技術者 が社会に対して負っている責任に関する理解

(c) 数学及び自然科学に関する知識とそれらを応用する 能力

(d) 当該分野において必要とされる専門的知識とそれら を応用する能力

（e）種々の科学, 技術及び情報を活用して社会の要求を 解決するためのデザイン能力

（f）論理的な記述力, 口頭発表力, 討議等のコミュニケ ーション能力

（g）自主的, 継続的に学習する能力

（h）与えられた制約の下で計画的に仕事を進め，まとめ る能力

（i）チームで仕事をするための能力

しかし，前述の「事例分析に基づいた技術者に求めら れる能力」に対して,「技術者に求められる能力」とし て, (a) (b) (e)では, 曖昧で具体的な内容としてわかり にくい.また, (c) (d) (f) (g) (h) (i)では, 基礎的すぎて 不十分である。例えば, (f) は学会発表に必要なコミュ ニケーション能力であり, 本当に技術者に求められる能 力とは, 公衆や社会の要望やニーズを聴いて適切にコミ ユニケーションできる能力である.

4.2 これからの工学教育が涵養すべき技術者の能力

「巨大化・総合化・複雑化，および不確実性下」の科 学技術の代表事例として,「福島原子力発電所」の事故原 因の分析から,「事例分析に基づいた技術者に求められる 能力」を分析し, さらにこれらを表 2 にて整理し，「こ れからの技術者に求められている能力」を整理し, (A)知 識, (B)態度, C)スキル, 横断的な能力として (1) から (6) にまとめた。 
表 2 事例分析に基づいた技術者に求められる能力

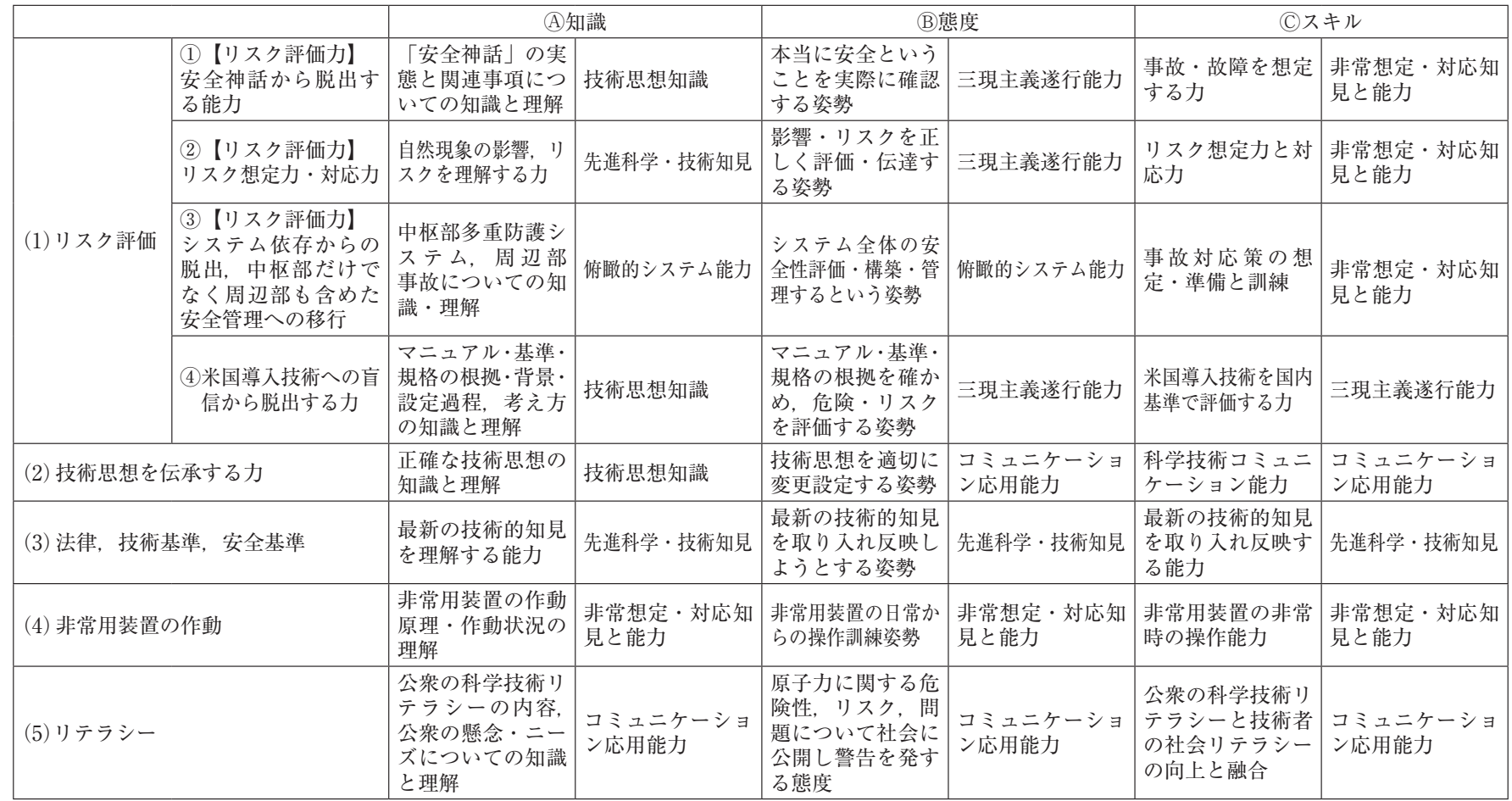

「JABEEで求められている技術者能力」に加えて, 追 加すべき能力を以下の通り提案する.

(1) 先進科学・技術知見

最新の先進的な科学・技術についての知見に関する能 力を身に付けることが必要である.

例えば「当時の世界最高の科学技術水準でも想定でき ない地震や津波などの自然現象」など「科学技術の不確 実性の影響やリスクを理解する能力」，さらには，「現行 の科学技術に関する法律，技術基準，安全基準にとらわ れず，科学技術の不確実性の下，それらに関する最新の 技術的知見についての知識を理解し，取り入れ反映しょ うとする姿勢, 反映する能力」が必要である.

そのためには, 自身の研究領域に閉じこもることなく, 過去の当時「想定外」と呼ばれた東日本大震災・津波な どの自然現象や，当時の科学技術的知見で解決すること ができなかった水俣病，BSEなどの「作動中の科学」の 事例研究を行うと同時に, 最新の先進的な科学・技術に ついて分野横断的な技術的知見を実体験で見聞すること が必要である.

(2) 技術思想知識

そもそも当該技術について, 開発・設置される普遍的 な前提条件や技術的な思想 (考え方), 知識を身に付ける 必要がある。例えば，福島原子力発電所事故以前に，原 子力業界で常態化されていた「原子力発電所の絶対安全」 「安全神話」という技術思想の内容, 根拠や関連事故事例 （スリーマイル島原発事故，チェルノブイリの原発事故 等)についての, 知識と理解が必要である。また，実際 に開発，導入された技術についてのマニュアル・基準・ 規格の根拠やその背景，設定された過程，考え方につい ての知識と理解が必要である.
そのためには，実際に技術思想に関連した事故事例 (地震の発生しない内陸部の大河近くに設置するという 米国仕様に基づいてフルターンキーで導入され，地震大 国の海岸近くに設置され津波被害から事故に繋がった福 島原子力発電所事例. 軽量で低速回転による安全運転を 技術思想として導入され, その後, 重量化, 高速化され リスクが増大し，ついに事故が発生した六本木回転ドア 事例）など技術思想に関する過去の事例研究を行うこと が必要である。また同時に，実際に開発，導入される技 術についての正確な技術思想の知識と理解, さらにはマ ニュアル・基準・規格の根拠やその背景, 設定された過 程, 考え方を常日頃から考察する訓練を行うことが必要 である。

（3）俯瞰的システム能力

システム全体を俯瞰し, 総合的評価・管理・判断する 能力を身に付けることが必要である.

例えば,「原子力発電所の中枢部多重防護システムを 中心とした安全管理システム」についての知識と理解, 「スリーマイル島原発事故等過去の類似の冷却材喪失事 故や周辺部に起因した事故」の事例研究を行うことが必 要である。また，実際に自身が設計，管理を行うシステ ムについて, 安全システムに依存するだけでなく, 自ら がシステムの中枢部分だけでなく周辺部も含めたシステ 厶全体の安全性評価・構築・管理するという姿勢が必要 である，そのためには，実際にハード面での対策と同時 に「想定外」を想定した防災訓練, あるは致命的な被害 には至らない減災訓練等のソフト面での対策も行うとい う姿勢が必要である。

（4）非常想定・対応知見と能力

非常時を想定し適切に対応できる知見と能力を身に付 
ける必要がある。

例えば, 福島原子力発電所事故事例研究等を通じて「想 定外」の巨大地震・巨大津波と, それに伴う原子力発電 所に関わる事故・故障を事前に想定する力を.さらに, 安全設備の準備等による柔軟な対応策の想定・準備と訓 練能力, 具体的な対応力を身に付けることが必要である. また，非常用装置についての作動原理・作動状況の理解 と日常からの操作訓練が必要である。また，実際に自身 が設計，管理を行うシステムについて，事故・故障の想 定, 対応策の想定・準備と訓練, 非常用装置についての 理解, 操作訓練が必要である.

（5）三現主義遂行能力

現場, 現物, 現実を確かめ課題を遂行するという三現 主義遂行能力を身に付ける必要がある。例えば, 過去の 巨大地震や巨大津波等の自然現象・リスクの実態を自ら 想定, 確認し, 現行の原子力発電所への影響, 公衆等へ のリスクを評価し，関係者に正しく伝えようとする姿勢 が必要である。また，実際に自分でマニュアル・基準・ 規格の根拠を確かめると同時に，危険・リスクを評価す る訓練, さらに, 海外からの導入技術を, 国内での安全 基準, 技術基準, 知見等に基づいて評価する訓練が必要 である。

（6）コミュニケーション応用能力

科学技術を通じて, 公衆や社会と適切にコミュニケー ションができる応用能力を身に付ける必要がある.

例えば，各開発·導入技術に潜在する危険性やリスク， さらに技術的あるいは倫理的な問題について，公衆の科 学技術リテラシーを向上させると同時に，その公衆の科 学技術リテラシーの内容さらに, 公衆の要望, ニーズ, 懸念について理解することが必要である.

そのためには, 各開発・導入技術について, 技術者と 公衆の双方向のコミュニケーション, 相互理解を通じて, 公衆に情報を適宜, 適切な方法で提供することにより, 情報公開し，公衆への説明責任を果たすことにより，公 衆の科学技術リテラシーの向上, 技術者の社会リテラシ 一の向上, 及び双方のリテラシーの融合を図る訓練をす ることが必要である。

\section{5. 今後の展望}

（1）今後さらに, 他事例も含め「巨大化・総合化・複雑 化, および不確実性下」の科学技術の事例分析を進 め, 「4.2 これからの工学教育が涵養すべき技術 者の能力」を整理し,「JABEEで求められている技 術者能力」, 工学教育について改善すべき点を整理, 精査し, 提案する。

(2)「4.2 これからの工学教育が涵養すべき技術者の 能力」(1)〜 (6) について, その内容をさらに具体化,
明確化する.

（3）「これからの工学教育が涵養すべき技術者の能力」を 身に付けるための具体的なカリキュラム, 具体策に ついて整理, 考察し, 提案する.

\section{参 考 文 献}

1 ）札野 順：技術者倫理, 放送大学教育振興会, pp.35 $-36,2004$

2 ) 藤垣裕子編 : 科学技術社会論の技法, 東京大学出版 会, pp. 225,2005

3 ) 東京電力福島原子力発電所事故調査委員会 (国会事 故調）：報告書, 2012.7.5

4 ) 東京電力福島原子力発電所における事故調查・検証 委員会 (政府事故調)：最終報告, 2012.7.23

5 ）福島原発事故独立検証委員会 (民間事故調)：調査 · 検証報告書, 2012. 3. 11

6 ) 東京電力 (東電事故調): 福島原子力事故調査報告書, 2012. 6. 20

7 ) 経済産業調査室・課 : 福島第一原発事故と 4 つの事 故調査委員会, 調查と情報第756号, 2012

8）田岡直規：原子力における技術者の社会的責任, 技 術倫理研究, 第 12 号, pp.41-58, 2015

9 ）藤森隆郎, 他：森林における野生生物の保護管理 生物多様性の保全に向けて, 日本林業調査会, pp.84, 1999

10）北海道新聞, 2011. 3. 26

11）宾倉正展, 岡村行信：平安の人々が見た巨大津波を 再現する一西暦869年貞観津波一, AFERC NEWS No.16, pp.1-10, 2010

12）田岡直規：巨大化・総合化・複雑化した科学技術に おける技術者倫理, 技術倫理研究, 第 8 号, pp.1732,2011

13）朝日新聞, 2011. 3. 31

14）朝日新聞, 2011. 4. 21

15）毎日新聞, 2011. 4. 19

16) JABEE HP, Webページ, http://www.jabee.org/

\section{著者紹介}

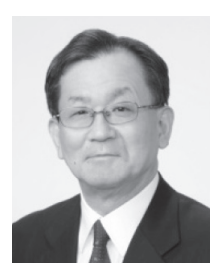

田岡 直規

1983年京都大学大学院工学研究科修士課程修了 (公社) 日本技術士会近畿本部副本部長, 技術士（機械· 総合技術監理部門), 京都大学・立命館大学・関西大学・ 岐阜大学等非常勤講師 専門分野 技術者倫理, 工学教育 